\title{
A Historical Perspective of the Maasai - African Wild Dog Conflict in the Serengeti Ecosystem
}

\author{
Richard D Lyamuya ${ }^{1,2}$, Emmanuel H Masenga ${ }^{1,2}$, Robert D Fyumagwa ${ }^{2}$, Machoke N \\ Mwita $^{2}$, Craig R Jackson ${ }^{3} \&$ Eivin Røskaft ${ }^{1}$ \\ ${ }^{1}$ Department of Biology, Norwegian University of Science and Technology (NTNU), Norway \\ ${ }^{2}$ Tanzania Wildlife Research Institute, P.O. Box 661, Arusha, Tanzania \\ ${ }^{3}$ Norwegian Institute of Nature Research, Trondheim, Norway \\ Correspondence: Eivin Røskaft, Department of Biology, Norwegian University of Science and Technology \\ (NTNU), Norway. E-mail:eivin.roskaft@ntnu.no
}

$\begin{array}{ll}\text { Received: March 2, } 2016 & \text { Accepted: March16, } 2016 \quad \text { Online Published: March 23, } 2016 \\ \text { doi:10.5539/enrr.v6n2p42 } & \text { URL: http://dx.doi.org/10.5539/enrr.v6n2p42 }\end{array}$

\begin{abstract}
This study discusses the conflict between Maasai pastoralists and African wild dogs (Lycaon pictus) over livestock before and after the Maasai were evicted from the Serengeti National Park (SNP) in 1959. We surveyed 181 randomly selected households from six villages in the eastern Serengeti ecosystem. A semi-structured questionnaire was used to acquire the required information from the respondents. We found that males had a greater awareness of local wild dog presence and livestock-derived conflict than females, and reported more frequently to have chased and killed wild dogs that attacked their livestock. Moreover, the conflict existed before 1959 , decreased during the 1990s, but increased from 2000 onwards. This increase is attributed to the growth in human, livestock and wild dog populations in the area. This study recommends that to foster their coexistence, the continued escalation in livestock numbers needs to cease while simultaneously protecting the region's wild prey populations.
\end{abstract}

Keywords: African wild dogs, predation, livestock, gender, conflict

\section{Introduction}

Human-carnivore conflict over livestock presents one of the most complex challenges facing wildlife management and conservation. This global problem (Ciucci \& Boitani, 1998; Rodney \& Rinchen, 2004; Røskaft, Bjerke, Kaltenborn, Linnell, \& Andersen, 2003; Røskaft, Händel, Bjerke, \& Kaltenborn, 2007; Treves \& Karanth, 2003; Woodroffe, Lindsey, Romanach, Stein, \& ole Ranah, 2005) is also a significant problem in the Serengeti ecosystem in northern Tanzania (Ikanda \& Packer, 2008; Jackson, Ahlborn, Gurung, \& Ale, 1996; Kaczensky, 1999; Larson, 2008). The most important driving factors include increasing human populations, loss of natural habitats and, in some regions, growing wildlife populations resulting from successful conservation programs (Wang \& Macdonald, 2006). The endangered African wild dog (Lycaon pictus) has disappeared from much of its former range, due mostly to conflict with humans (Ogada, Woodroffe, Oguge, \& Frank, 2003; Rasmussen, 1999; Treves \& Karanth, 2003) which has led to their population decline (Swarner, 2004; Woodroffe et al., 2005). This endangered species has been reported to prey on livestock wherever it comes into contact with domestic animals (Lyamuya, Masenga, Fyumagwa, \& Røskaft, 2014; Rasmussen, 1999; Swarner, 2004; Woodroffe et al., 2005). The Maasai pastoralists in the eastern Serengeti ecosystem are among those suffering livestock losses to wild dogs (Lyamuya et al., 2014; Masenga, 2011). The Maasai pastoralists have inhabited the Serengeti and Ngorongoro areas until the end of the eighteenth century, arriving from the north and displacing other tribes in the Serengeti area (e.g., Sukuma, Ikoma and Ndorobo) (Neumann, 1995). They became the dominant ethnic group in the Serengeti by the late 1800s (Homewood \& Rodgers, 1991). Since then, the Maasai pastoralists in the Serengeti area have lived alongside wild animals, including the African wild dogs, up to 1959 when they were evicted from the Serengeti National Park and displaced to the Loliondo Game Controlled Area (LGCA) and Ngorongoro Conservation Area (NCA) (Neumann, 1995). Before that, the African wild dog population was most likely high, yet the wild dogs were declared locally extinct in the Serengeti National Park (SNP) in 1991 (Carbone et al., 2005; Gascoyne, Laurenson, Lelo, \& Borner, 1993; Stearns \& Stearns, 1999). A recent genetic study, however, has indicated that while the packs inside the national park disappeared, the population never went extinct and most probably survived in adjoining areas (Marsden, Wayne, \& Mable, 2012). 
Wild dogs currently inhabiting LGCA and NCA are genetically similar to those previously inhabiting the Serengeti plains, ruling out the possibility that this population has recolonized the area from elsewhere (Marsden et al., 2012). The LGCA and NCA support the only wild dog population in the area since the population has failed to naturally recolonize the Serengeti National Park (Masenga, 2011).

Therefore, there is little information on the historical distribution of wild dogs in the ecosystem, especially as to where the population successfully survived the supposed local extinction. There is also a lack of information as to whether the Maasai pastoralists had any conflict with the wild dogs over their livestock during their stay in the SNP before 1959, and whether this has escalated in recent years. Information on the status of the conflict will thus provide a much needed overview of the historical distribution of wild dogs and temporal trends in the conflict in the area. Insights into the conflict will aid conservation management of the threatened carnivore.

We tested three hypotheses in this study. The first hypothesis was that the wild dogs have continuously inhabited the LGCA, even directly after the reported extinction. The second hypothesis is that male Maasai pastoralists have a greater awareness of local wild dog presence and the livestock-derived conflict in their area. The third hypothesis is that the conflict between the Maasai pastoralists and wild dogs has increased in recent years due to human and livestock population growth and an increase in the wild dog population in the area.

\section{Materials and Methods}

The study was conducted in six villages in the LGCA in the eastern Serengeti ecosystem (Figure 1). LGCA borders the Maasai Mara National Reserve along the Kenyan border and the SNP in Tanzania between $2^{\circ} 5^{\prime} 00^{\prime \prime}-2^{\circ} 2^{\prime} 60^{\prime \prime} \mathrm{S}$ and $35^{\circ} 61^{\prime} 67^{\prime}$ ' $-35^{\circ} 37^{\prime} 00^{\prime \prime} \mathrm{E}$ (Masenga, 2011). The region is one of the most wildlife-rich areas in the world (Maddox, 2003). Hundreds of thousands of wildebeest (Connochaetes taurinus), zebra (Equus burchelli) and other ungulates pass through the communities during their annual migration from the Maasai Mara to the Serengeti Plains (Holdo et al., 2010). Large predators remain remarkably widespread throughout the LGCA compared with nominally unprotected areas in other parts of Tanzania and neighbouring countries. Maddox (2003) described a significant cheetah (Acinonyx jubatus) population in the LGCA and noted the large numbers of lions (Panthera leo), spotted hyenas (Crocuta crocuta), and jackals (Canis mesomelas) in the area. The Maasai pastoralists mostly inhabit the area closest to the SNP boundary, covering approximately $4500 \mathrm{~km}^{2}$ (Lyamuya, Masenga, Fyumagwa, \& Røskaft, 2014). The dominant form of land use and livelihood in the area is trans-human pastoralism (Homewood \& Rodgers, 1991), which utilizes wet and dry season livestock grazing pastures according to traditional patterns of movement. Rangelands are managed communally but are not considered to be open access lands.

The data for this study were collected in January 2013 and encompassed 181 households chosen randomly from the six Maasai villages living in the eastern Serengeti ecosystem (Figure 1). The method used for data collection and sample size determination followed the same methods previously employed in other studies (Fa, Peres, \& Meeuwig, 2002; Sancheti \& Kapoor, 2003). No prior notice was given to the interviewees, although the village chairman was first consulted about the study and asked for permission to carry out interviews in his/her area. A purposive sampling strategy was used, with respondents chosen according to availability based on their age and gender. A semi-structured interview was administered through a questionnaire translated into "Swahili" language with the help of Maasai translators to acquire information related to their perspectives on the history of human-wild dog conflict in the area. The information collected included basic information such as the respondent's age, GPS location, tribe (only Maasai), educational level (e.g., had been to school, had not been to school) and occupation (e.g., livestock keeper, housewife, employee). Respondents were then asked if they were born before or after the Maasai eviction from the SNP. After that, respondents were asked the following questions regarding their coexistence with wild dogs: (1) "Have you ever seen wild dogs?" (2) "How often do you see wild dogs in your area?" (3) "How is the general population trend of wild dogs in your area?" (4) "Have you ever seen wild dogs preying on your livestock?" (5) "How often do you see wild dogs preying on your livestock?" (6) "How did you react when you observed wild dogs attacking your livestock?; (7) "If you compare the present situation on livestock attacks by wild dogs to those days when you were young, is it increasing, decreasing or does it remain stable?"

During the survey, we collected village centre GPS locations which assisted us in drawing our study area map in Arc View 9.0 (Environmental Systems Research Institute, Redlands, CA, USA). Statistical Package for Social Science (SPSS) Statistics 21.0 for Windows (http://www.spss.com) was used to perform all statistical analyses (Kirkpatrick \& Feeney, 2010). We used both logistic and linear regression analyses to test different independent variables that could explain the variations existing among dependent variables in our data. Because most of our data were nominal, we primarily used non-parametric Chi-square tests (Fowler, Cohen, \& Jarvis, 2009) to determine frequency differences among different variables; hence, in all tests, $\mathrm{P} \leq 0.05$ was considered statistically significant. 


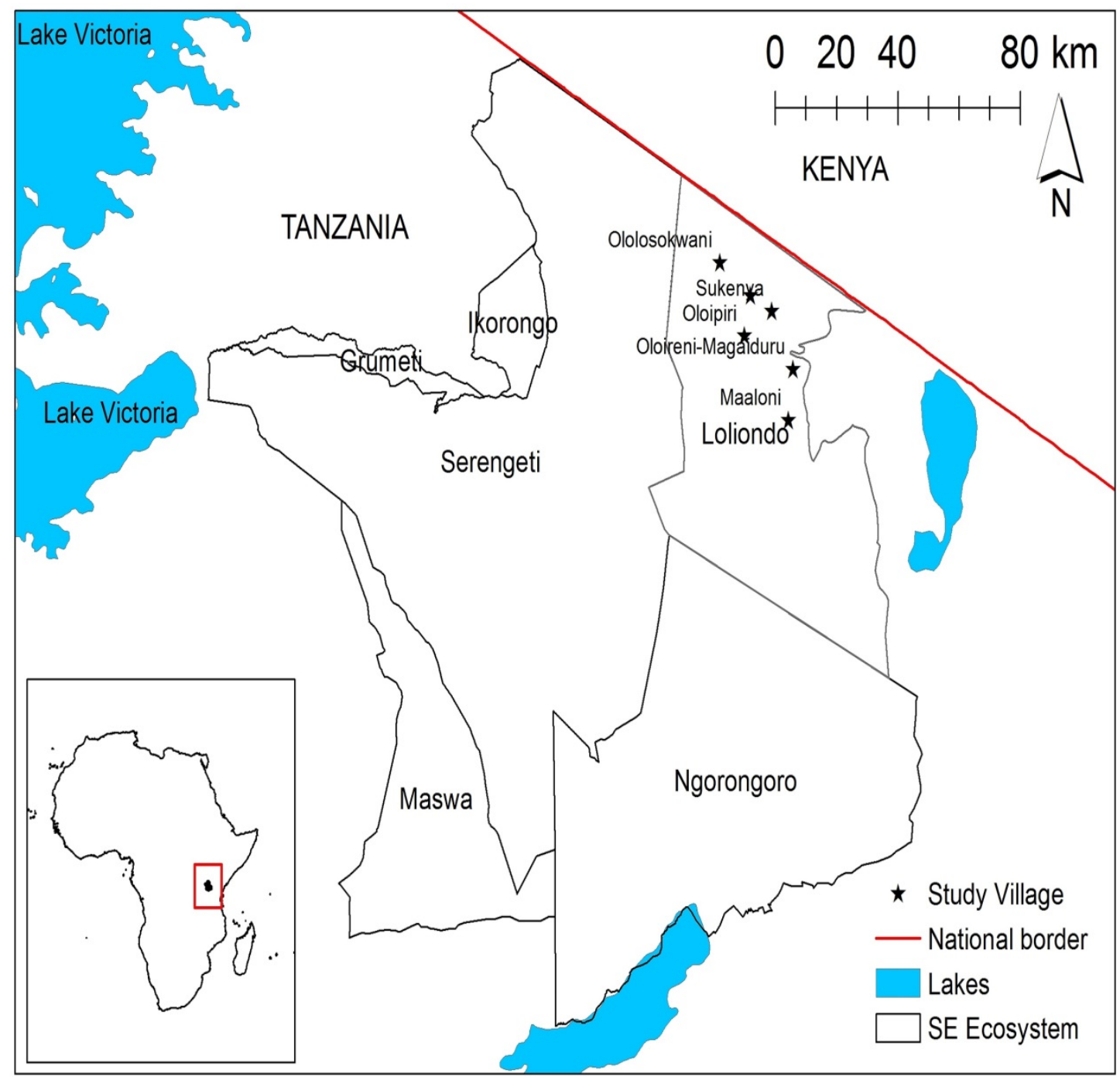

Figure 1. A map of the Serengeti ecosystem showing the study area with the surveyed villages marked with stars

\section{Results}

Male Maasai pastoralists $(98 \%, \mathrm{n}=123)$ reported more frequently to have seen wild dogs in their area than did females $\left(66 \%, \mathrm{n}=58 ; \chi^{2}{ }_{1}=36.5, \mathrm{P}=0.001\right)$. Those who had been to school had more frequently $(95 \%, \mathrm{n}=74)$ seen wild dogs in the area than those who had never been to school $\left(82 \%, \mathrm{n}=107 ; \chi^{2}{ }_{1}=6.02, \mathrm{P}=0.014\right)$. However, no difference in this respect was found between those born before or after the eviction from SNP (1959) $\left(\chi_{1}^{2}=\right.$ $0.479, \mathrm{P}=0.359$ ).

A logistic regression analysis with response to the question "Have you ever seen wild dogs? (yes/no)" as a dependent variable, and gender, education level and born before or after eviction from the SNP (1959) as independent variables indicated that gender $(\mathrm{B}=2.7$, Wald $=15.8, \mathrm{P} \leq 0.001)$ was the only factor explaining whether wild dogs had been seen in their area (Wald $\chi_{3}{ }_{3}=32.7, \mathrm{P} \leq 0.001$, Nagelkerke $\mathrm{r}^{2}=0.328$ ). The other factors such as born before or after the Maasai eviction from the SNP and education level were not found to be significant in explaining the variation in the observations (yes/no) of wild dogs in the area.

Males more frequently reported seeing wild dogs on a daily or weekly basis compared to females $\left(\chi^{2}{ }_{1}=39.2, \mathrm{P} \leq\right.$ 0.001 , Table 1). Furthermore, the frequency on how often Maasai pastoralist had observed wild dogs varied with education level $\left(\chi_{1}^{2}=17.1, \mathrm{P}=0.002\right.$, Table 1$)$ and whether they were born before or after the eviction from SNP $\left(\chi_{1}^{2}=33.6, \mathrm{P} \leq 0.001\right.$, Table 1). Those who not had been to school observed wild dogs more frequent than those who had been to school, while those born before eviction from the SNP (1959) also observed wild dogs more common than those born after eviction. 
Table 1. Responses to the question "How often do you see African wild dogs in your area?" in relation to gender, education level or whether born before or after the eviction from Serengeti National Park (1959)

\begin{tabular}{llllllll}
\hline Frequency & & Daily & Weekly & Monthly & Rarely & Never & $n$ \\
\hline \multirow{3}{*}{ Gender } & & $\%$ & $\%$ & $\%$ & $\%$ & $\%$ & \\
& Males & 24 & 27 & 12 & 35 & 2 & 123 \\
\multirow{4}{*}{ Education } & Females & 14 & 10 & 9 & 33 & 35 & 58 \\
& No school & 27 & 18 & 8 & 30 & 18 & 107 \\
& Been to school & 11 & 27 & 16 & 41 & 5 & 74 \\
& Before & 35 & 28 & 11 & 15 & 10 & 79 \\
& After & 9 & 17 & 11 & 49 & 15 & 102 \\
\hline
\end{tabular}

Furthermore, a linear regression analysis with how often Maasai pastoralist have observed wild dogs in their area as a dependent variable and with gender, education level and born before/after eviction as independent variables was significant $\left(\mathrm{F}_{3,177}=23.3, \mathrm{r}^{2}=0.283, \mathrm{P}<0.001\right)$. Here both born before/after eviction $\left(\mathrm{B}=1.11, \mathrm{t}_{1}=6.07, \mathrm{P} \leq\right.$ $0.001)$ and gender $\left(B=1.09, t_{1}=5.64, P \leq 0.001\right)$ explained the variation significantly, while education level did not.

Most males $(55 \%, \mathrm{n}=123)$ reported that the wild dog population was decreasing in the area while most females $(45 \%, \mathrm{n}=58)$, indicated that the population was increasing $\left(\chi^{2}{ }_{1}=32.7, \mathrm{P} \leq 0.001\right)$. The assessment of the wild dog population trend also differed between the two groups with different education levels $\left(\chi_{1}^{2}=15.3, \mathrm{P}=0.002\right)$. Most of those who had been to school (46\%) thought the population was increasing while a majority of those who had never been to school $(23 \%)$ had no opinion. No difference in this assessment of the current population trend was found between those born before or after eviction from the $\operatorname{SNP}\left(\chi^{2}{ }_{1}=5.37, \mathrm{P}=0.15\right)$. A linear regression analysis with assessment of the population trend as a dependent variable and with gender, education level and born before or after the eviction from SNP as independent variables was significant $\left(\mathrm{F}_{3,177}=2.84\right.$, Nagelkerker ${ }^{2}=0.046$, $\mathrm{P}=0.039)$, however, only gender $\left(\mathrm{B}=0.297, \mathrm{t}_{1}=1.74, \mathrm{P}=0.083\right)$ explained some of this variation, while education level and born before or after the eviction from SNP did not.

Males $(81 \%, \mathrm{n}=123)$ reported more frequently than females $(50 \%, \mathrm{n}=58)$ having seen wild dogs preying on their livestock $\left(\chi^{2}{ }_{1}=18.9, \mathrm{P} \leq 0.001\right)$. Furthermore, those who had been to school more frequently $(81 \%, \mathrm{n}=74)$ reported to have seen wild dogs preying on their livestock than those who had never been to school $(65 \%, \mathrm{n}=$ $\left.107 ; \chi^{2}{ }_{1}=5.9, \mathrm{P}=0.015\right)$. However, no difference in this respect was found between those born before or after eviction $\left(\chi^{2}{ }_{1}=0.58, \mathrm{P}=0.445\right)$. Logistic regression with wild dogs preying on livestock as a dependent variable and with gender, education level and born before or after eviction as independent variables were significant (Wald $\chi_{3}{ }_{3}=30.6, \mathrm{P} \leq 0.001$, Nagelkerke $\left.\mathrm{r}^{2}=0.156\right)$. Gender $\left(\mathrm{B}=1.38\right.$, Wald $\left.\chi^{2}{ }_{1}=13.7, \mathrm{P} \leq 0.001\right)$ was, however, the only factor explaining whether wild dogs had been seen preying on their livestock in their area while education level and born before or after the eviction from SNP was non-significant.

Although most respondents had seen wild dogs preying on their livestock rarely in their area the frequencies differed between the two gender $\left(\chi^{2}{ }_{1}=23.9, \mathrm{P} \leq 0.001\right)$, the two education groups $\left(\chi^{2}{ }_{1}=10.7, \mathrm{P}=0.015\right)$, but not in relation to whether they were born before or after the eviction from $\operatorname{SNP}\left(\chi^{2}{ }_{1}=3.52, \mathrm{P}=0.32\right)$. A linear regression analysis how often do you see wild dogs preying on your livestock as a dependent variable and with gender, education level and born before or after the eviction from SNP as independent variables was significant $\left(\mathrm{F}_{3,177}=6.81, \mathrm{P}=0.039\right)$, however, only gender $\left(\mathrm{B}=0.406, \mathrm{t}_{1}=3.61, \mathrm{P}=0.001\right)$ explained some of the variation, while education level and born before or after the eviction from SNP did not.

Males reported more frequently chasing or killing wild dogs when they saw them attacking their livestock than did females $\left(\chi^{2}{ }_{1}=10.8, P=0.005\right.$, Table 2$)$. However, no differences in this reaction patterns were found concerning education level $(\mathrm{P}=0.32)$ or between those born before or after the eviction from $\mathrm{SNP}(\mathrm{P}=0.23)$.

More males $(71 \%)$ than females $(50 \%)$ claimed that the present situation recording wild dog attacks is increasing compared to previous days $\left(\chi^{2}{ }_{3}=12.7, \mathrm{P}=0.005\right.$, Table 3$)$, similarly $75 \%$ among those born before the eviction from SNP claimed the wild dog attacks on livestock is increasing while only $56 \%$ of those born after the eviction claimed so $\left(\chi^{2}{ }_{3}=13.6, \mathrm{P}=0.004\right.$, Table 3$)$. No difference in this respect was found between those with or without education $(\mathrm{P}=0.85)$. 
A linear regression analysis with "If you compare the present situation on livestock attacks by wild dogs to those days when you were young, is it increasing, decreasing or does it remain stable?" as a dependent variable and with gender, education level and born before or after the eviction from SNP as independent variables was significant $\left(F_{3,177}=8.89, P \leq 0.001\right)$. Born before or after the eviction from SNP $\left(B=0.656, t_{l}=3.82, P \leq\right.$ $0.001)$ and gender $\left(B=0.621, t_{1}=3.31, P \leq 0.001\right)$ significantly explained this variation, while education level did not.

Table 2: Responses to the question "How did you react when you observed African wild dogs attacking your livestock?" in relation to gender

\begin{tabular}{lcccc}
\hline Gender & $\begin{array}{c}\text { I chase them away } \\
\text { or kill them } \\
\%\end{array}$ & $\begin{array}{c}\text { I try to find help } \\
\text { or do nothing } \\
\%\end{array}$ & $\begin{array}{c}\text { Wild dogs flee when } \\
\text { they see people }\end{array}$ & $n$ \\
\hline Males & 57 & 19 & $\%$ & \\
Females & 32 & 18 & 50 & 44 \\
\hline
\end{tabular}

Table 3. Responses to the question "If you compare the present situation on livestock attacks by wild dogs to those days when you were young, is it increasing, decreasing or remains stable?" in relation to gender (only those born before 1959)

\begin{tabular}{lllll}
\hline & & Elder males & Elder females & $n$ \\
\hline Increasing & $\%$ & 74 & 26 & 42 \\
Stable & $\%$ & 25 & 75 & 4 \\
Decreasing & $\%$ & 83 & 17 & 6 \\
No opinion & $\%$ & 50 & 50 & 2 \\
TOTAL & $\%$ & 70 & 30 & 54 \\
\hline
\end{tabular}

\section{Discussion}

Our results reveal that male Maasai pastoralists more frequently reported having seen wild dogs in their area than did females. This finding supports our hypothesis that male Maasai pastoralists have a greater awareness of local wild dog presence in their area. This is because male Maasai normally follow the livestock out into the bush (Mmassy \& Røskaft, 2013) and therefore, acquire more information. Also, this finding indicates that wild dogs were present in the LGCA long before and even after the Maasai were evicted from the SNP in 1959. Therefore, our results support our hypothesis that the wild dogs have continuously inhabited the LGCA, even directly after the reported extinction as from the results of the genetic study conducted by Marsden et al. (2012), indicated that the Serengeti population of African wild dogs did not go extinct in the region as previously reported (Stearns \& Stearns, 1999). While Marsden et al. (2012) did postulate that the population may have survived unrecorded in the Loliondo region, our results confirm this and that the population has persisted there subsequently.

Furthermore, our results show that wild dogs were sighted more often by Male pastoralists on a daily or weekly basis compared to females, which supports our hypothesis that male Maasai pastoralists have a greater awareness of local wild dog presence in their area. Moreover, those born before eviction from the SNP (1959) also observed wild dogs more frequent than those born after eviction, because before 1959, the population of the African wild dogs in the area was most likely high (Carbone et al., 2005; Frame, Malcolm, Frame, \& Vanlawick, 1979) and thus, those born before eviction from SNP were able to see more often than those born after eviction. Also, those born after eviction experienced more of the reported decline of African wild dogs in the SNP during the 1990s (Carbone et al., 2005; Stearns \& Stearns, 1999) which reduced their chances to see wild dogs more frequently in the area. However, since 2000 onwards, the African wild dogs have been reported to be sighted more frequently in the LGCAand has increased to some extent their chances of being sighted in the area (H. E. Masenga \& Mentzel, 2005).

In explaining the general population trend of wild dogs in the area, it was found that most males reported that wild dog population was decreasing while most females reported it was increasing. The reported decrease in wild dog population by males was probably because its population observed before 1990 was most likely high, but despite 
their initially high numbers, African wild dogs were declared locally extinct in the Serengeti National Park (SNP) in 1991 (Carbone et al., 2005; Gascoyne et al., 1993; Stearns \& Stearns, 1999). Due to the division of labour within the Maasai pastoralist society (FAO, 2013; Mmassy \& Røskaft, 2013), males were expected to observe and be more aware of changes in the wild dog population.

Our results also supported the hypothesis that male Maasai pastoralists were more concious of the conflict over livestock with wild dogs in their area since male Maasai pastoralists reported more frequently than females to have seen wild dogs, especially those preying on livestock. This finding may be attributed to the existing division of labour within the Maasai pastoralist society which favours males doing outdoor activities such as daily livestock herding (FAO, 2013; Mmassy \& Røskaft, 2013), whereas females mostly do domestic work such as caring for children, cooking, milking livestock, fetching water and firewood collection (Mwebi, 2007). Our findings further indicate that the Maasai conflict with African wild dogs existed before their eviction from the SNP in 1959, but conflict occurred at a low level.

Males reported more frequently than females that they had seen wild dogs preying on their livestock, albeit rarely, which is in support of our hypothesis that male Maasai pastoralists are more aware of the conflict over livestock with wild dogs in their area than female Maasai. The rarity of sighting livestock depredation incidences by males Maasai is attributed to the abundant wild prey species reported to be found in the area (Grzimek \& Grzimek, 1960; Thirgood et al., 2004) and also because previous studies have found no difference in terms of species diversity and density of both ungulates and carnivores between the SNP and its surrounding areas (Campbell \& Borner, 1995; Maddox, 2003). Wild dogs have been found to prefer to prey on wild prey species rather than livestock wherever wild prey species are more abundant (Hayward, O'Brien, Hofmeyr, \& Kerley, 2006; Rasmussen, 1999).

According to our results, males more frequently reported that they chased and killed wild dogs when they saw them preying on livestock. Therefore, our findings support previous studies showing that most livestock keepers do retaliate by killing problem animals following livestock losses (Bangs \& Shivik, 2001; Gese, 2003; Ikanda \& Packer, 2008; Kissui, 2008; Maddox, 2003; E. H. Masenga et al., 2013), which have brought some carnivore species close to local extinction (Rasmussen, 1999; Woodroffe et al., 2005), the African wild dog being one such species (Swarner, 2004; Woodroffe et al., 2005).

Our findings concur with the previous studies as more males and those born before the eviction from SNP claimed that the present situation on livestock attacks by wild dogs is increasing, supporting our hypothesis that this conflict has risen in recent years due to human population growth and an increase in the wild dog population in the area. The human population at the time of eviction was small, comprising around 1000 Maasai pastoralists (Neumann, 1998), whereas recent settlements in the Ngorongoro district number more than 180,000 Maasai pastoralists (Homewood \& Rodgers, 1991). This increase in number of livestock in the area has probably increased the rate of wild dogs encounters (Lyamuya et al., 2014; E. H. Masenga et al., 2013; H. E. Masenga \& Mentzel, 2005). Our findings support what previous studies indicating that the endangered African wild dog population posed no significant problem to the Maasai pastoralists in the Serengeti Ecosystem (Ikanda \& Packer, 2008; Maddox, 2003). This was perhaps because of the reported extinction of the African wild dogs in 1991 (Carbone et al., 2005; Creel, Creel, \& Monfort, 1997; Gascoyne et al., 1993; Stearns \& Stearns, 1999) that reflected a reduction in their numbers to a such extent that wild dogs were not easily detected (Marsden et al., 2012). Therefore, this conflict was considered to decrease during that period (Ikanda \& Packer, 2008; Maddox, 2003) and then increased again from 2000 onwards (H. E. Masenga \& Mentzel, 2005). Given wild dogs' wide-ranging behaviour, attacks on livestock would most likely have been low when the human and livestock population was small. The increase in the wild dog, human and livestock populations thus intensifies the probability of encounter and attacks.

\section{Conclusion}

This study confirms that male Maasai pastoralists have a greater awareness of local wild dog presence and the livestock-derived conflict in their area. Moreover, the conflict between the Maasai pastoralists and African wild dogs over livestock existed before 1959 and has continued to present days. Furthermore, wild dogs did not go completely extinct from the Serengeti ecosystem in 1991 and managed to survive in other areas including the LGCA (Burrows, Hofer, \& East Marion, 1994; Marsden et al., 2012). Conflict decreased in 1990s and has increased in recent years. This study suggests that for the Maasai pastoralists to coexist better with African wild dogs, the continuing rise in livestock density needs to cease while wild prey population should be protected.

\section{References}

Bangs, E., \& Shivik, J. (2001). Managing wolf conflict with livestock in the Northwestern United States. Carnivore Damage Prevention News, 2-5. 
Burrows, R., Hofer, H., \& East Marion, L. (1994). Demography, extinction and intervention in a small population: The case of the Serengeti wild dogs. Proceedings of the Royal Society of London - Series B: Biological Sciences, 256(1347), 281-292.

Campbell, K., \& Borner, M. (1995). Population trends and distribution of Serengeti herbivores: implications and management. In A. R. E. Sinclair \& P. Arcese (Eds.), Serengeti II: Dynamics, management and conservation of an ecosystem (pp. 117-145). Chicago, Ill: University of Chicago Press.

Carbone, C., Frame, L., Frame, G., Malcolm, J., Fanshawe, J., FitzGibbon, C., \& du Toit, J. T. (2005). Feeding success of African wild dogs (Lycaon pictus) in the Serengeti: the effects of group size and kleptoparasitis. Journal of Zoology, London, 266, 153-161.

Ciucci, P., \& Boitani, L. (1998). Wolf and dog depredation on livestock in central Italy. Wildlife Society Bulletin, 26(3), 504-514.Retrieved from $<$ Go to ISI $>$ ://BIOABS:BACD199900096141

Creel, S., Creel, M. N., \& Monfort, S. L. (1997). Radio collaring and stress hormones in African wild dogs. Conservation Biology, 11(2), 544-548.

Fa, J. E., Peres, C. A., \& Meeuwig, J. (2002). Bushmeat exploitation in tropical forests: an intercontinental comparison. Conservation Biology, 16(1), 232-237.Retrieved from http://www.blackwellsynergy.com/links/doi/10.1046/j.1523-1739.2002.00275.x/abs

FAO. (2013). Children's work in the livestock sector: Herding and beyond (ISBN 978-92-5-107387-2).

Fowler, J., Cohen, L., \& Jarvis, P. (2009). Practical statistics for field biology (2nd ed.). London, UK: Wiley.

Frame, L. H., Malcolm, J. R., Frame, G. W., \&Vanlawick, H. (1979). Social organization of African wild dogs (Lycaon pictus) on the Serengeti-Plains, Tanzania 1967-1978. ZeitschriftFürTierpsychologie, 50(3), 225249.Retrieved from $<$ Go to ISI $>$ ://A1979HS91700001

Gascoyne, S. C., Laurenson, M. K., Lelo, S., \& Borner, M. (1993). Rabies in African wild dogs (Lycaon pictus) in the Serengeti region, Tanzania. Journal of Wildlife Diseases, 29(3), 396-402.Retrieved from $<$ Go to ISI $>$ ://A1993LM64200004

Gese, E. M. (2003). Management of carnivore predation as a means to reduce livestock losses:the study of coyotes (Canislatrans) in North America Paper presented at the $1^{\text {st }}$ Work shop sobrePesquisa e Consevaca de CarnivorosNeotropicais, Atibaia, Sao Paulo, Brasil.

Grzimek, M., \& Grzimek, B. (1960). Census of plains animals in the Serengeti. Journal of Wildlife Management, 24, 27-61.

Hayward, M. W., O'Brien, J., Hofmeyr, M., \& Kerley, G. I. H. (2006). Prey preferences of the African wild dog Lycaon pictus (Canidae: Carnivora): Ecological requirements for conservation. Journal of Mammalogy, 87(6), $1122-1131$.

Holdo, R. M., Galvin, K. A., Knapp, E., Polasky, S., Hilborn, R., \& Holt, R. D. (2010). Responses to alternative rainfall regimes and antipoaching in a migratory system. Ecological Applications, 20(2), 381-397.Retrieved from $<$ Go to ISI $>$ ://000276635600006

Homewood, K. M., \& Rodgers, W. A. (1991). Maasailand ecology: Pastoralist development and wildlife conservation in Ngorongoro, Tanzania (Vol. Cambridge University Press). Cambridge, UK.

Ikanda, D., \& Packer, C. (2008). Ritual versus retaliatory killings of African lions in the Ngorongoro Conservation Area, Tanzania. Endangered Species Research, 6, 67-74.

Jackson, R. M., Ahlborn, G. G., Gurung, M., \& Ale, S. (1996). Reducing livestock depredation losses in the Nepalese Himalaya. Paper presented at the 17th Vertebrate Pest Conferrence.

Kaczensky, P. (1999). Large carnivore depredation on livestock in Europe. Ursus, 11, 59-72.

Kirkpatrick, L. A., \& Feeney, B. C. (2010). A simple guide to SPSS, Version 17.0. Belmont, CA: Wadsworth.

Kissui, B. M. (2008). Livestock predation by lions, leopards, spotted hyenas, and their vulnerability to retaliatory killing in the Massai Steppe, Tanzania. Animal Conservation, 11, 422-432. http://dx.doi.org/10.1111/j.14691795.2008.00199.x

Larson, C. L. (2008). Separating people and wildlife: Zoning as a conservation strategy for large carnivores. (Degree of Bachelor of Arts with honors in Environmental Studies), Colby College, Waterville, Maine. Retrieved from http://digitalcommons.colby.edu/honorstheses/245 
Lyamuya, R., Masenga, E., Fyumagwa, R., \& Røskaft, E. (2014). Human-carnivore conflict over livestock in the eastern part of the Serengeti ecosystem, with a particular focus on the African wild dog Lycaon pictus. Oryx, 48(3), 378-384. http://dx.doi.org/10.1017/S0030605312001706

Maddox, T. M. (2003). The ecology of cheetahs and other carnivores in pastoralist-dominated buffer zone. (PhD), Zoological Society of London, London.

Marsden, C. D., Wayne, R. K., \& Mable, B. K. (2012). Inferring the ancestry of African wild dogs that returned to the Serengeti-Mara. Conservation Genetics, 13(2), 525-533. doi:DOI 10.1007/s10592-011-0304-z

Masenga, E. H., Lyamuya, R. D., Nyaki, A., Kuya, S., Jaco, A., Kohi, E., \& Røskaft, E. (2013). Strychnine poisoning in African wild dogs (Lycaon pictus) in the Loliondo game controlled area, Tanzania. International Journal of Biodiversity and Conservation, 5(6), 367-370. http://dx.doi.org/10.5897/IJBC12.100

Masenga, H. E. (2011). Abundance, distribution and conservation threats of African wild dogs (Lycaon pictus) in the Loliondo Game Controlled Area,Tanzania. (MSc), Sokoine University of Agriculture, Morogoro, Tanzania.

Masenga, H. E., \& Mentzel, C. (2005). The African wild dogs (Lycaon pictus); Preliminary results from a newly established population in Serengeti-Ngorongoro ecosystem, northern Tanzania. Paper presented at the Proceedings of fifth annual TAWIRI scientific conference Arusha, Arusha, Tanzania.

Mmassy, E. C., \& Røskaft, E. (2013). Knowledge on birds of conservation interest among the people living close to protected areas in Serengeti, Northern Tanzania. International Journal of Biodiversity Science, Ecosystem Services \& Management, 9(2), 114-122. http://dx.doi.org/10.1080/21513732.2013.788566

Msuha, M. J. (2009). Human impacts on carnivore biodiversity inside and outside protected areas in Tanzania $(\mathrm{PhD})$, University College London and Institute of Zoology, Zoological Society of London London, UK.

Mwebi, O. (2007). Herding efficiency as a factor in the human-carnivore conflict in Kenya: A comparative study of the Laikipa and Mbirikani group ranches. Retrieved from London South Bank University, Nairobi-Kenya:

Neumann, R. P. (1995). Local challenges to global agendas: Conservation, economic liberalization and the pastoralists's rights movement in Tanzania. Antipode, 27, 363.

Neumann, R. P. (1998). Imposing wilderness: struggle over livelihood and nature preservation in Africa. Berkely, NJ, USA: University of California Press.

Ogada, M. O., Woodroffe, R., Oguge, N. O., \& Frank, L. G. (2003). Limiting depredation by African carnivores: the role of livestock husbandry. Conservation Biology, 17(6), 1521-1530. http://dx.doi.org/10.1111/j.15231739.2003.00061.x

Rasmussen, G. S. A. (1999). Livestock predation by the painted hunting dog Lycaon pictus in a cattle ranching region of Zimbabwe: a case study. Biological Conservation, 88(1), 133-139.Retrieved from $<$ Go to ISI $>: / / 000078180000013$

Rodney, M. J., \& Rinchen, W. (2004). A community-based approach to mitigating livestock depredation by snow leopards. Human Dimensions of Wildlife, 9, 307-315.

Røskaft, E., Bjerke, T., Kaltenborn, B. P., Linnell, J. D. C., \& Andersen, R. (2003). Patterns of self-reported fear towards large carnivores among the Norwegian public. Evolution and Human Behavior, 24(3), 184-198.doi: http://dx.doi.org/10.1016/S1090-5138(03)00011-4

Røskaft, E., Händel, B., Bjerke, T., \&Kaltenborn, B. P. (2007). Human attitudes towards large carnivores in Norway. Wildlife Biology, 13(2), 172-185. http://dx.doi.org/10.2981/09096396(2007)13[172:HATLCI]2.0.CO;2

Sancheti, D. C., \& Kapoor, V. K. (2003). Statistics theory, methods and application. Dublin: Sultan Chand and Sons.

Stearns, P. B., \& Stearns, S. C. (1999). Watching from the edge of extinction. In P. B. Stearns \& S. C. Stearns (Eds.), Watching from the edge of extinction. New Haven \& London: Yale University Press.

Swarner, M. (2004). Human-carnivore conflict and perspectives on carnivore management world wide,.Conservation Biology, 17, 1491-1499.

Thirgood, S., Mosser, A., Tham, S., Hopcraft, G., Mwangomo, E., Mlengeya, T., \& Borner, M. (2004). Can parks protect migratory ungulates? The case of the Serengeti wildebeest. Animal Conservation, 7, 113120.Retrieved from $<$ Go to ISI $>$ ://000221970100001 
Treves, A., \& Karanth, K. U. (2003). Human-carnivore conflict and perspectives on Carnivore management worldwide. Conservation Biology, 17(6), 1491-1499. Retrieved from http://www.blackwell-synergy.com/ links/doi/10.1111/j.1523-1739.2003.00059.x/abs

Wang, S. W., \& Macdonald, D. W. (2006). Livestock predation by carnivores in Jigme Singye Wangchuck National Park, Bhutan. Biological Conservation, 129, 558-565.

Woodroffe, R., Lindsey, P., Romanach, S., Stein, A., \& ole Ranah, S. M. K. (2005). Livestock predation by endangered African wild dogs (Lycaon pictus) in northern Kenya. Biological Conservation, 124(2), 225-234. http://dx.doi.org/10.1016/j.biocon.2005.01.028

\section{Copyrights}

Copyright for this article is retained by the author(s), with first publication rights granted to the journal.

This is an open-access article distributed under the terms and conditions of the Creative Commons Attribution license (http://creativecommons.org/licenses/by/3.0/). 